\title{
Nurmisäilörehun sulamattoman kuidun mittaaminen NIRS -menetelmällä
}

\author{
Juha Nousiainen ${ }^{1)}$, Seppo Ahvenjärvi ${ }^{2)}$, Marketta Rinne ${ }^{2)}$, Laura Nyholm ${ }^{1)}$, Maria Hellämäki ${ }^{1)}$ ja Pekka \\ Huhtanen $^{2)}$ \\ ${ }^{1)}$ Valio Oy, Alkutuotanto ja jäsensuhteet, PL 20,00039Valio, etunimi.sukunimi@valio.fi \\ ${ }^{2)}$ MTT, Kotieläintuotannon tutkimus, Eläinravitsemus, 31600 Jokioinen, etunimi.sukunimi@mtt.fi
}

\section{Johdanto}

Rehunsulatuskinetiikkaa systemaattisesti mallintamalla on osoitettu, että karkearehun sulavuuteen märehtijöillä vaikuttaa oleellisesti potentiaalisesti sulavan solunseinämäkuidun (DNDF) pitoisuus, koska solunsisällysaineet [= orgaaninen aine $(\mathrm{OA})$ - solunseinämäkuitu (NDF)] sulavat käytännössä täydellisesti (Allen \& Mertens 1988). Lisäksi sulavuuteen vaikuttavat DNDF:n sulatus- $\left(k_{d}\right)$ ja virtausnopeus $\left(k_{p}\right)$. Sulava NDF määritetään NDF:n ja sulamattoman NDF:n (INDF) erotuksena. Tämä tekee INDF:stä mielenkiintoisen ja tärkeän uuden rehuparametrin. Sitä voidaan hyödyntää dynaamisissa pötsimalleissa (mm. Pohjoismainen Karoline malli) tai empiirisissä yhtälöissä OA:n sulavuuden ennustamiseksi perinteisiä rehuarvoja laskettaessa (Nousiainen ym. 2003). Karoline mallin simuloinneissa on osoitettu, että INDF on tärkein rehunannoksen sulavuuteen ja myös lehmien valkuaisen saantiin vaikuttava yksittäinen rehuparametri (Huhtanen, suullinen tiedonanto).

Nurmirehun INDF:n määrä ja siten sulavuus on riippuvainen solunseinän lignifioitumisesta. Lignifioitumiseen puolestaan vaikuttavat tunnetusti nurmen korjuuaste, säätekijät ja jossain määrin myös kasvilaji. Kuitenkaan sulavuuden tai INDF:n ennustaminen regressioyhtälöillä ligniinipitoisuuden avulla ei ole kovin tarkkaa, koska ligniini ei ole mm. nurmen kasvuolosuhteista johtuen homogeeninen solunseinän komponentti (Nousiainen ym. 2003). Lisäksi viileässä ilmastossa kasvavissa nurmissa absoluuttinen ligniinipitoisuus on varsin alhainen ja ligniinianalyysin virhe on kuitenkin pitoisuudesta riippumaton vakio. Tutkimustarkoituksiin INDF on määritetty pitkällä $(>10 \mathrm{pv})$ pötsiuitolla pienisilmäisiä $(<20 \mu \mathrm{m})$ nailonpusseja käyttäen. Toisaalta INDF on voitu mitata pitkällä $(144 \mathrm{~h})$ in vitro -inkubaatiolla pötsinesteessä $(\mathrm{mm}$. Traxler ym. 1998) tai se on laskettu perinteisistä nailonpussimenetelmän parametreista. Pitkässä in vitro -inkubaatiossa on kuitenkin vaikeaa ylläpitää hyvää kuidunsulatustehokkuutta siten että kaikki DNDF sulaisi. Eräissä menetelmissä pötsineste vaihdetaan 48 tunnin kohdalla sulatustehokkuuden ylläpitämiseksi. Perinteisen nailonpussimenetelmän parametreista INDF on mahdollista ennustaa suhteellisen hyvin, edellyttäen että inkubointiajat on valittu sopivasti. Hankaluutena menetelmässä on se, että optimaalinen inkubointiaika riippuu rehun laadusta. Lisäksi päätepistemittaukseen verrattuna menetelmä on hyvin työläs. Näillä perusteilla arvioiden luotattavin menetelmä INDF:lle lienee pitkä uitto pienisilmäisessä nailonpussissa. Toisaalta tilanäytteiden mittaamiksi tarvitaan helpompi massamenetelmä.

Lähi-infrapunaheijastusspektroskopialla (NIRS) on varsin menestyksellisesti voitu mitata säilörehun biologisia ominaisuuksia (sulavuus, sulatusnopeus ja käymislaatu) vaikka itse menetelmä yksinkertaisesti mittaa vain rehunäytteen orgaanisten yhdisteiden sisältämien $\mathrm{O}-\mathrm{H}, \mathrm{C}-\mathrm{H}$ ja $\mathrm{N}-\mathrm{H}$-sidosten aiheuttamaa valon absorptiota (Deaville ja Flinn, 2000). Kyse on siis ei-spesifisestä menetelmästä kun mitataan sulavuutta, koska sekä täysin sulavat että täysin sulamattomat rehun komponentit sisältävät infra-puna-alueen aallonpituudella absorboivia sidoksia. Menetelmän etuna on hyvä toistettavuus, jolloin referenssimenetelmän tarkkuus ja kalibrointiaineiston kattavuus ratkaisevat lopullisen mittaustarkkuuden tuntemattomia tilanäytteitä analysoitaessa Tässä työssä tutkittiin NIR-spektrin korrelaatiota nurmisäilörehun INDF - pitoisuuteen sekä sen ennustamista yleisesti käytetyillä NIRS kalibrointimenetelmillä, kun referenssinä käytetään pitkää pötsiuittoa pienisilmäisessä nailonpussissa.

\section{Aineisto ja menetelmät}

Tutkimusaineistona käytettiin säilörehunäytteitä, jotka korjattiin eri kasvuasteilla timotei-nurminadan kevät- $(\mathrm{n}=27)$ tai jälkisadosta $(\mathrm{n}=25)$ Jokioisilla vuosina $1994,1996-2000$ ja 2002. Lisäksi kerättiin nurmen kevät- ja jälkisadon tilasäilörehunäytteitä $(n=42)$ vuosilta 1999-2002. Tilanäytteet valittiin isommasta joukosta rehuja pepsiini-sellulaasiliukoisuuden ja NIR -spektrin perusteella mahdollisimman suuren vaihtelun varmistamiseksi. Rehuista analysoitiin solunseinämän komponentit (NDF ja ligniini) standardimenetelmin. INDF määritettiin pitkällä $(288 \mathrm{~h})$ pötsiuitolla sekä koesäilörehuista ( $6 \mu \mathrm{m}$ nailonpussit) että tilanäytteistä (17 $\mu \mathrm{m}$ nailonpussit) kahdella karkearehuvaltaisella ruokinnalla olevalla lehmällä. Lisäksi koesäilörehuilla tehtiin normaali sulavuuskoe pässeillä kokonaiskeruumenetelmällä. INDF laskettiin NDF:n ja pötsiuiton tuhkakorjatun NDF pesujäännöksen erotuksena. Kuivattujen ja jauhettujen (1-mm seula) rehunäytteiden heijastusspektrit mitattiin NIR -laitteella (Foss NIRSystems 6500) aallonpituusvälillä 400-2498 nm $2 \mathrm{~nm}: n$ välein. Lopulliseen laskentaan 
käytettiin normalisoituja (keskiarvo = 0), de-trend -korjattuja (Barnes ym. 1989) ja derivoituja spektrejä (SNVD) väliltä 1100-2500 nm (700 heijastusdatapistettä/spektri). Spektreistä laskettiin INDF:lle korrelaatiospektri ja kalibrointi MPLS -menetelmällä, jota on yleisimmin käytetty nurmisäilörehuja mitattaessa (Park ym. 1997). Lisäksi laskettiin SNV-D keskiarvoerotusspektri sellaisten säilörehujen välille, joissa oli INDF alle $40(n=7)$ tai yli $130 \mathrm{~g} / \mathrm{kg} \mathrm{KA}(\mathrm{n}=10)]$.

Taulukko 1. Nurmisäilörehunäytteiden koostumus, NDF:n laatu ja sulavuus(n $=94)$

\begin{tabular}{lrrrr}
\hline & Keskiarvo & Keskihajonta & Minimi & Maksimi \\
\hline Kuiva-aine (g/kg) & 236 & 52,7 & 151 & 466 \\
Koostumus (g/kg KA) & & & & \\
$\quad$ Tuhka & 81 & 15,5 & 51 & 120 \\
$\quad$ Raakavalkuainen & 155 & 28,3 & 103 & 239 \\
NDF & 556 & 64,9 & 402 & 669 \\
INDF & 87 & 32,8 & 17 & 167 \\
Ligniini & 29 & 8,4 & 13 & 55 \\
$\quad$ Solun sisällysaineet & 370 & 51,8 & 265 & 507 \\
NDF:n laatu (g/kg) & & & & \\
$\quad$ INDF/NDF & 157 & 54,7 & 40 & 291 \\
Ligniini/NDF & 53 & 12,3 & 29 & 107 \\
$\quad$ Ligniini/INDF & 378 & 179,8 & 219 & 1397 \\
Sulavuus pässeillä (g/kg) & & & & \\
$\quad$ Orgaaninen aine & 714 & 56,0 & 610 & 840 \\
$\quad$ NDF & 722 & 67,1 & 584 & 869 \\
DNDF (=NDF - INDF) & 865 & 35,2 & 791 & 929 \\
\hline
\end{tabular}

\section{Tulokset ja tulosten tarkastelu}

Rehujen koostumuksessa oli runsaasti vaihtelua, mikä on perusedellytys hyvälle NIRS -kalibroinnille (Taulukko 1). Rehujen keskimääräinen INDF -pitoisuus oli $87 \mathrm{~g} / \mathrm{kg} \mathrm{KA}$, ollen kevätsadon rehuilla pienempi kuin jälkisadolla (83 vs. $118 \mathrm{~g} / \mathrm{kg} \mathrm{KA}$ ). Pässit sulattivat keskimäärin $865 \mathrm{~g} / \mathrm{kg}$ säilörehujen DNDF:stä, kun NDF:n kokonaissulavuus oli $714 \mathrm{~g} / \mathrm{kg}$. Jälkikasvun DNDF:n sulavuus oli merkitsevästi parempi kuin kevätsadolla (877 vs. $853 \mathrm{~g} / \mathrm{kg}$ ). Tulosten perusteella kevät- ja jälkikasvun rehujen NDF:n laatu on erilainen, mikä vahvistaa aikaisemmin saatuja havaintoja sekä pässien sulavuus- että lehmien maidontuotantokokeista. Rehujen INDF pitoisuus korreloi vahvasti pässeillä määritetyn $\mathrm{OA}: n$ sulavuuden $\left(\mathrm{R}^{2}=0,900\right)$ kanssa, ja ao. regressioyhtälöt eivät poikenneet oleellisesti eri satojen välillä toisistaan. Vastaava tulos havaittiin jo aikaisemmassa tutkimuksessa (Nousiainen ym. 2003).

Erotusspektri (Kuvio 1) osoitti, että NIR -spektrissä on useita alueita joissa INDF:n korkeat ja matalat pitoisuudet erottuvat toisistaan. Selvimmin erot näkyivät spektrin loppuosassa $(>2000 \mathrm{~nm})$, ja tällä alueella tiedetään olevan mm. ligniinin spesifinen absorptio. On kuitenkin huomattava, että korrelaatiospektrin huiput eivät ole kaikki samoja kuin erotusspektrillä. Tämä johtuu todennäköisesti siitä, että sekä hyvin että huonosti sulavissa rehuissa on samoja sidoksia jotka absorboivat valoa samalla lailla. Toisaalta suhteellisen pienikin ligniinipitoisuuden muutos voi aikaansaada ison sulavuusmuutoksen. Tästä on esimerkkinä aallonpituus 1670 nm, jossa tiedetään olevan ligniinin spesifinen absorptiokohta. Negatiivinen erotusspektrin arvo on tällä kohden varsin pieni, mutta samalla kohtaa on suhteellisen korkea positiivinen INDF:n korrelaatiohuippu (Kuvio 1). NIRS -korrelaatiospektrit olivat samanmuotoiset sekä ligniinille että INDF:lle, mutta yleensä korrelaatiohuiput olivat korkeampia INDF:1le aallonpituusalueella $<2200 \mathrm{~nm}$. Tämä johtunee ainakin osaksi INDF:n suuremmasta vaihtelusta ligniiniin verrattuna rehun kasvuasteen muuttuessa.

Kalibrointitulosten mukaan (Taulukko 2) säilörehun INDF - pitoisuus on mahdollista mitata varsin tarkasti NIRS - menetelmällä. Kalibroinnin kokonaisselitysaste $\left(\mathrm{R}^{2}=0,949\right)$ ilman poikkeavia pisteitä on erittäin korkea, kun sitä vertaa yksittäisiin korrelaatiohuippuihin (Kuvio 1). Tämä on selitettävissä siten, että NIRS spektrissä on runsaasti informaatiota nimenomaan käyrän muodoissa, ei niinkään yksittäisissä absorptiohuipuissa. Tästä syystä kalibroinnissa käytetään yleensä 1. ja 2. asteen derivaattamuunnoksia, koska ne reagoivat käyrien muotoon herkemmin kuin suorat absorptiospektrit ilman matemaattisia käsittelyitä. Tässä tutkimuksessa käytettiin 1 . asteen derivaattaa, mutta kalibrointia edelleen kehitettäessä on syytä kokeilla myös 2. asteen derivaattaa (vrt. Park ym. 1997). Validoinnin ennustevirhe (SECV, taulukko 2) on selvästi suurempi kuin kalibroinnin virhe. Validoinnin ennustevirhe antaa kuitenkin luotettavamman kuvan kalibroinnin toimivuudesta tuntemattomia tilanäytteitä mitat-taessa. Aineiston hajonnan ja validointivirheen suhteen perusteella $(3,33)$ INDF -kalibrointi on riittävän tarkka

Taulukko 2. NIRS kalibrointi- ja validointistatistiikka nurmisäilörehun INDF -pitoisuudelle (g/kg KA) 


\begin{tabular}{|c|c|c|c|c|c|c|c|c|}
\hline \multicolumn{6}{|c|}{ Kalibrointi } & \multicolumn{3}{|c|}{ Validointi } \\
\hline $\begin{array}{r}\text { Näytteiden } \\
\text { määrä }\end{array}$ & $\begin{array}{r}\text { Termien } \\
\text { määrä }\end{array}$ & Keskiarvo & SD & $\mathrm{SEC}^{\mathrm{b}}$ & $\mathrm{R}^{2}$ & $\mathrm{SECV}^{\mathrm{c}}$ & $\overline{\mathrm{R}^{2}}$ & $\mathrm{SD} / \mathrm{SECV}$ \\
\hline 94 & 8 & 87 & 32,8 & 10,3 & 0,901 & 14,2 & 0,814 & 2,31 \\
\hline $88^{\mathrm{a}}$ & 9 & 86 & 33,3 & 7,5 & 0,949 & 10,0 & 0,910 & 3,33 \\
\hline
\end{tabular}

${ }^{\mathrm{a}}$ Kalibroinnista poistettu poikkeavat näytteet; ${ }^{\mathrm{b}}$ Kalibroinnin ennustevirhe; ${ }^{\mathrm{c}}$ Validoinnin ennustevirhe

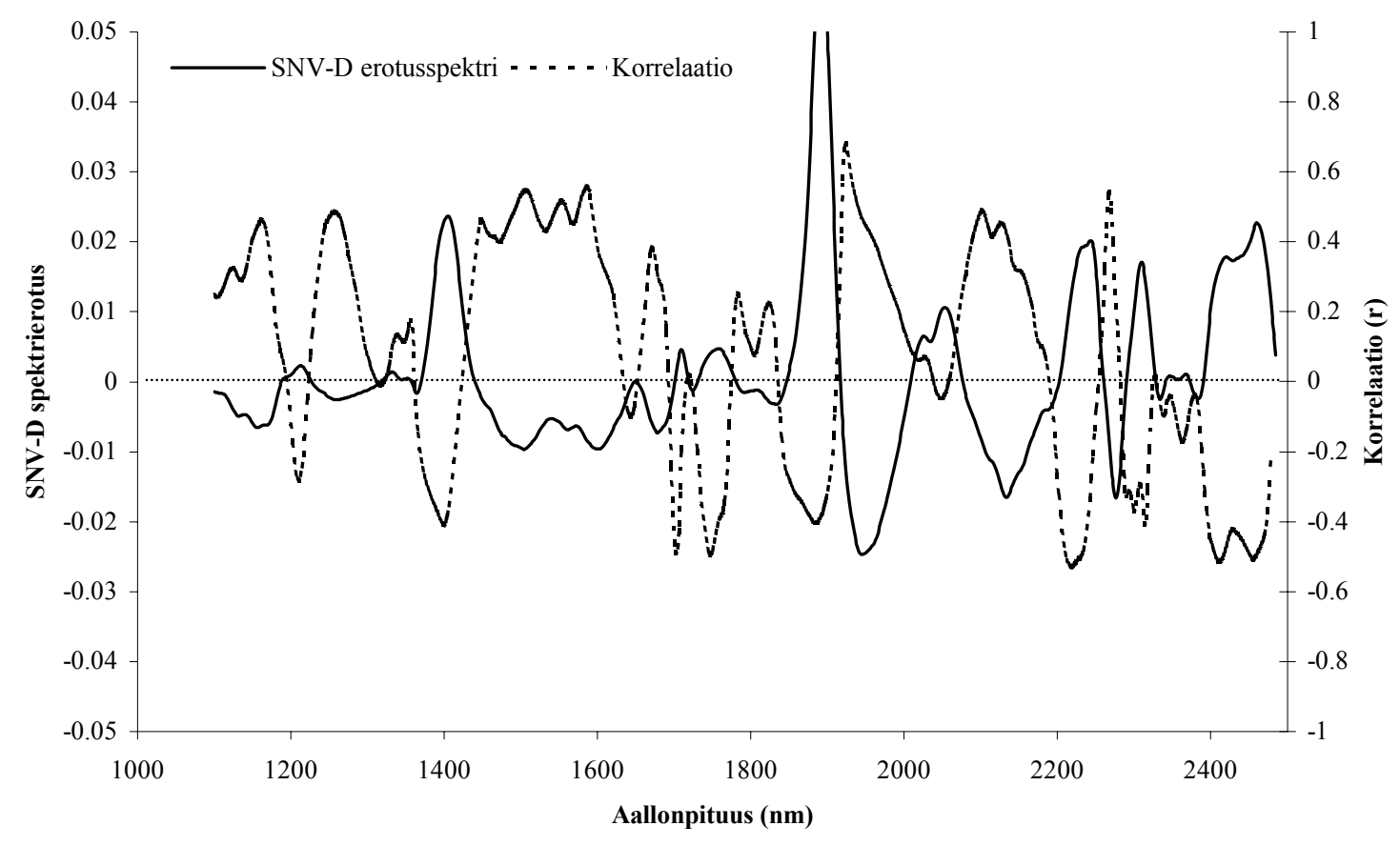

Kuvio 1. SNV-D erotusspektri [INDF $<40 \mathrm{~g} / \mathrm{kg} \mathrm{KA}(\mathrm{n}=7)-\mathrm{INDF}>130 \mathrm{~g} / \mathrm{kg} \mathrm{KA}(\mathrm{n}=10)$ ] sekä SNV-D korrelaatiospektri INDF pitoisuuteen verrattuna $(n=94)$

Taulukko 3. Regressioanalyysin tulokset (ennustettu vs. mitattu) mitattaessa nurmisäilörehun INDF -pitoisuus (g/kg KA) NIRS kalibroinnilla (kalibrointi sisälsi kaikki näytteet, $\mathrm{n}=94$ )

\begin{tabular}{|c|c|c|c|c|c|c|c|c|}
\hline \multirow[b]{2}{*}{$\begin{array}{l}\text { Rehunäyte- } \\
\text { sarja }\end{array}$} & \multicolumn{5}{|c|}{ Regressio } & \multicolumn{3}{|c|}{ Osuus SEP:stä } \\
\hline & $\begin{array}{l}\text { Keskim. } \\
\text { virhe }^{\mathrm{a}}\end{array}$ & $\begin{array}{r}\text { Leikkaus- } \\
\text { piste }\end{array}$ & $\begin{array}{l}\text { Kulma- } \\
\text { kerroin }\end{array}$ & SEP & $\mathrm{R}^{2}$ & $\begin{array}{r}\text { Leikkaus- } \\
\text { piste }\end{array}$ & $\begin{array}{l}\text { Kulma- } \\
\text { kerroin }\end{array}$ & $\begin{array}{l}\text { Satunnais- } \\
\text { virhe }\end{array}$ \\
\hline Koerehut/Kevätsato & 0,5 & 3,1 & 0,95 & 9,16 & 0,952 & 0,003 & 0,042 & 0,955 \\
\hline Koerehut/Jälkisato & $-3,4$ & $-5,5$ & 1,08 & 9,09 & 0,915 & 0,138 & 0,053 & 0,809 \\
\hline Tilanäytteet & 1,7 & 3,2 & 0,94 & 11,18 & 0,781 & 0,023 & 0,014 & 0,963 \\
\hline Kaikki & 0,0 & 0,0 & 1,00 & 9,91 & 0,909 & $<0,001$ & $<0,001$ & $>0,999$ \\
\hline
\end{tabular}

${ }^{\mathrm{a}}$ Ennustettu - Mitattu

kvantitatiiviseen mittaukseen. Tämän suhteen pitäisi olla yli 2,5 hyväksyttävälle NIRS -kalibroinnille. Havaittu ennustevirhe INDF:lle (10 g/kg KA) vastaa OA:n sulavuutena noin $14 \mathrm{~g} / \mathrm{kg}$ (Nousiainen ym. 2003). Tämä virhe on samaa tasoa kuin tämän aineiston pässien sulavuuskokeiden yhdistetty hajonta OA:n sulavuudelle.

Keskimäärin koko aineistossa INDF:n NIRS - ennusteet olivat harhattomia ja riippumattomia INDF:n pitoisuudesta, koska käytännössä virhe oli kokonaan satunnaista (Taulukko 3). Myös kevätsadon koerehuilla ja tilarehuilla virhe oli pääosin satunnaista. Toisaalta jälkisadon koerehuille kalibrointi antoi systemaattisesti hieman liian pienen $(-3,4 \mathrm{~g} / \mathrm{kg} \mathrm{KA}) \mathrm{INDF}$-ennusteen, jolloin varsin suuri osa ennustevirheestä oli tästä johtuvaa $(0,138)$. Tulos on hieman yllättävä, koska kalibrointiaineisto sisälsi tasapainoisesti kaikkia satoja. Aikaisemmin on tosin todettu, että solunseinämän rakenne on jälkisadon nurmisäilörehulla erilainen ja vaihtelevampi kuin kevätsadolla. Lisäksi ennustettaessa OA:n sulavuutta on ennustevirhe ollut useissa tutkimuksissa suurempi jälkisadolla menetelmästä riippumatta. Ennustettaessa nurmisäilörehun D-arvoa yhdellä NIRS kalibroinnilla, on myös havaittu liian korkeita tuloksia nimenomaan jälkisadolle. Kaikki tämä viittaa siihen, että jälkisadon rehut ovat heterogeenisempiä, ja niille on vaikeampi kehittää kalibrointia. Syytä tähän ei vielä tarkkaan tunneta.

Tässä tutkimuksessa ligniini korreloi merkitsevästi INDF -pitoisuuden kanssa, mutta koko aineistosta laskettu lineaarinen tai epälineaarinen regressioyhtälö ennusti INDF -pitoisuuden epätarkasti $\left(R^{2}<0,4\right.$; Taulukko 4$)$. Tämä johtui toisaalta satunnaisvirheestä, sekä ligniinipitoisuuden erilaisesta yhteydestä NDF:n sulavuuteen kevät- ja jälkisadon rehuilla (Nousiainen ym. 2003). Tulos vahvistaa aiempaa käsitystä siitä, että ligniinipitoisuu- 
den avulla on vaikea ennustaa rehun sulavuutta taikka INDF pitoisuutta viileän ilmaston hyvälaatuisille nurmirehuille. Joissakin rehuarvojärjestelmissä (esim. NRC) ligniinin avulla ennustetaan INDF (Traxler ym. 1998), mutta tällöin sekä ligniinin että INDF:n absoluuttiset pitoisuudet ovat selvästi Suomen olosuhteita korkeampia. NRC:n kaavat johtaisivat selvästi liian alhaisiin sulavuuksiin jos niitä käytettäisiin Suomessa. Lisäksi virhe kasvaisi rehun laadun parantuessa. Perinteisistä rehuanalyyseista paras INDF:n ennustemenetelmä oli regressioyhtälö, jossa selittäjinä olivat OA:n pepsiini-sellulaasi -liukoisuus ja NDF (ennustevirhe $15,6 \mathrm{~g} / \mathrm{kg} \mathrm{KA} \mathrm{ja} \mathrm{\textrm {R } ^ { 2 } =}$ $0,830)$.

Uusissa dynaamisissa rehuarvosysteemeissä tarvitaan ainakin säilörehulle analyysitulos NDF:lle ja joko DNDF:lle tai INDF:1le. Sulavan NDF:n ennustaminen suoralla NIR -kalibroinnilla onnistui tässä aineistossa myös varsin hyvin $\left(\mathrm{R}^{2}=0,841\right)$, mutta laskenta NDF:n ja INDF:n NIRS -ennusteiden erotuksena oli hieman parempi $\left(\mathrm{R}^{2}=0,880\right)$. Koska rehun NDF - pitoisuus tarvitaan märehtijöiden rehunsulatusmalleissa joka tapauksessa, tulee kalibrointien kehittäminen jatkossa keskittää INDF:n mittaamiseen. Tässä työssä kehitetty kalibrointi ei saaduista hyvistä tuloksista huolimatta ole todennäköisesti riittävän kattava tilarehunäytteitä mitattaessa. Tämä johtuu siitä, että vaikka NIRS on toistettavuudeltaan yleensä parempi kuin kemialliset menetelmät, on kalibrointiaineistossa oltava monipuolisesti edustettuina kaikki sellaiset rehutyypit (= spektrityypit), joita tiloillakin esiintyy. Tämä tarkoittaa että hyvä tuotantokalibrointi esimerkiksi nurmisäilörehulle voi sisältää yli 300 näytettä. Kalibroinnin jatkuva kehittäminen on myös tärkeää. Tämä johtuu osittain siitä, että modernit NIRS menetelmät hyödyntävät koko spektrin informaation hyväkseen, ja pienikin spektrin poikkeavuus voi johtaa suureen ennustevirheeseen. Tästä syystä validoinnilla pyritään optimoimaan regressiotermien määrää, jotta kalibroinnista ei tulisi liian herkkä.

Taulukko 4. Yhteenveto eri menetelmistä ennustettaessa nurmisäilörehun INDF - pitoisuutta regressioanalyysilla

\begin{tabular}{|c|c|c|c|c|c|c|}
\hline Menetelmä & Keskiarvo & $\begin{array}{l}\text { Keskim. } \\
\text { virhe }^{\mathrm{b}}\end{array}$ & SEP & $\mathrm{R}^{2}$ & $\mathrm{SD} / \mathrm{SEP}$ & Lähde \\
\hline NIRS & 86,9 & 0,0 & $8,86^{\mathrm{c}}$ & 0,945 & 4,28 & Tämä tutkimus \\
\hline $\mathrm{SL}^{\mathrm{a}}, \mathrm{g} / \mathrm{kg} \mathrm{KA}$ & 96,8 & 9,9 & 20,30 & 0,714 & 1,87 & Tämä tutkimus \\
\hline Ligniini, g/kg KA & 92,9 & 6,0 & 30,43 & 0,356 & 1,25 & Tämä tutkimus \\
\hline Ligniini, g/kg NDF ${ }^{\mathrm{d}}$ & 93,5 & 6,6 & 31,20 & 0,321 & 1,22 & Tämä tutkimus \\
\hline SL, Ligniini & 93,6 & 6,7 & 19,40 & 0,740 & 1,95 & Tämä tutkimus \\
\hline SL, NDF & 91,0 & 4,1 & 15,64 & 0,830 & 2,42 & Tämä tutkimus \\
\hline Ligniini, g/kg KA & 85,9 & $-1,0$ & 30,97 & 0,333 & 1,22 & Traxler ym. 1998 \\
\hline
\end{tabular}

${ }^{\mathrm{a}}$ Orgaanisen aineen pepsiini-sellulaasiliukoisuus; ${ }^{\mathrm{b}}$ Ennustettu - Mitattu; ${ }^{\mathrm{c}}$ Ennustettu vs. mitattu; ${ }^{\mathrm{d}}$ Ei-lineaarinen malli $(\mathrm{Y}=$ $\left.1+\mathrm{X}^{1.155}\right)$

\section{Johtopäätökset}

Matemaattisesti muunnetun (SNV-D + 1. derivaatta) NIR -spektrin ja säilörehun INDF-pitoisuuden välillä esiintyi korrelaatiohuppuja useilla spektrin alueilla. Toisaalta parhaatkin yksittäiset korrelaatiohuiput olivat suhteellisen alhaisia (välillä $-0,7>\mathrm{r}<0,7$ ), mikä on tyypillistä NIR -spektreille. Tästä huolimatta koko aineistosta laskettu NIR -kalibrointi ennusti INDF:n selvästi paremmin kuin mikään rehun kemialliseen komponenttiin perustuva regressiomenetelmä (validoinnin ennustevirhe $10 \mathrm{~g} / \mathrm{kg} \mathrm{KA} \mathrm{ja} \mathrm{R}^{2}=0,910$ ). Seuraavaksi paras INDF:n ennustemenetelmä oli regressioyhtälö, jossa selittäjinä olivat OA:n pepsiini-sellulaasi -liukoisuus ja NDF (ennustevirhe 15,6 g/kg KA ja ${ }^{2}=0,830$ ). Vaikka NIR -ennustevirheet ovat kalibrointien ulkopuolisia tilanäytteitä mitattaessa todennäköisesti hieman tässä aineistossa havaittuja suurempia, osoittavat tulokset NIRS menetelmällä olevan potentiaalia ennustaa riittävän luotettavasti dynaamisissa sulatusmalleissa tarvittava tärkein rehuparametri. Seuraavaksi tulisi tutkia myös sulatusnopeuden $\left(k_{d}\right)$ ennustusmahdollisuutta. Jo tätä ennen voidaan INDF -kalibrointia hyödyntää empiirisissä yhtälöissä säilörehun OA:n sulavuuden ennustamisessa. Lisäksi on vakavasti pohdittava, muutetaanko nurmisäilörehujen D-arvo -kalibrointi INDF:ään perustuvaksi. Tällä hetkellä ao. kalibrointi pohjautuu OA:n pepsiini-sellulaasi-liukoisuuteen, jolloin ilmeisesti tarvitaan kasvilaji-ja laboratoriokohtaiset korjausyhtälöt OA:n sulavuuden ja D-arvon ennustamiseksi.

\section{Kirjallisuus}

Allen, M.S. \& Mertens, D.R. 1988. Evaluating constraints of fiber digestion by rumen microbes. J. Nutr. 118:261-270.

Barnes, R.J., Dhanoa, M.S. \& Lister, S.J. 1989. Standard normal variate transformation and de-trending of near-infrared diffuse reflectance spectra. Appl. Spectrosc. 43, 772-777.

Deaville, E.R. \& Flinn, P.C. 2000. Near-infrared (NIR) spectroscopy: an alternative approach for the estimation of forage quality and voluntary intake. Julkaisussa Givens, D.I., Owen, E., Axford, R.F.E. and Omed, H.M., (toim.), Forage Evaluation in Ruminant Nutrition, CABI Publishing, Oxon, s. 301-320. 
Nousiainen, J., Rinne, M., Hellämäki, M. \& Huhtanen, P. 2003. Prediction of the digestibility of the primary growth and regrowth grass silages from chemical composition, pepsin-cellulase solubility and indigestible cell wall content. Anim. Feed Sci. Technol. 110:61-74.

Park, S., Gordon, F.J., Angnew, R.S., Barnes, R.J. \& Steen, R.W.J. 1997. The use of near infrared reflectance spectroscopy on dried samples to predict biological parameters of grass silage. Anim. Feed Sci. Technol. 68, 235-246. Traxler, M.J., Fox, D.G., Van Soest, P.J., Pell, A.N., Lascano, C.E., Lanna, D.P.D., Moore, J.E., Lana, R.P., Vélez, M., Flores, A. 1998. Predicting forage indigestible NDF from lignin concentration. J. Anim. Sci. 76:1469-1480 